\title{
Cholinergic regulation of the phosphoinositide second messenger system in the guinea pig organ of Corti ${ }^{1}$
}

\author{
Andrew S. Niedzielski, Toshiyuki Ono and Jochen Schacht \\ Kresge Hearing Research Institute, University of Michigan, Ann Arbor, Michigan, USA
}

(Received 29 September 1991; accepted 15 January 1992)

\begin{abstract}
The effect of cholinergic agents on the phosphoinositide second messenger system was investigated in the cochlea of the adult guinea pig in vivo and in vitro. In vivo, phospholipids were labeled with [ $\left.{ }^{32} \mathrm{P}\right]$-orthophosphate by perilymphatic perfusion and their hydrolysis assayed in 'chase' experiments with non-radioactive orthophosphate. Carbachol $(1 \mathrm{mM})$ reduced the content of ${ }^{32}$ P-labeled phosphatidylinosito' 4,5 -bisphosphate in the organ of Corti from $31 \%$ to $21 \%$ of total ${ }^{32} \mathrm{P}$-lipids, indicating stimulated hydrolysis. The pharmacology of this effect was studied in detail in vitro via the release of inositol phosphates from phosphoinositides pre-labeled with ${ }^{3} \mathrm{H}$-inositol. Release was increased 2 -fold by $1 \mathrm{mM}$ carbachol, 1.6 -fold by $1 \mathrm{mM}$ muscarine, but was unaffected by dimethylphenylpiperazinium; the stimulation was blocked by $1 \mu: M$ atropine but not mecamylamine. These responses indicate the coupling of phosphoinositides to a muscarinic receptor. Furthermore, stimulated inositol phosphate release was higher in the base of the organ of Corti than in the apex which correlates with the increased cholinergic efferent innervation of outer hair cells in the basal region. These results suggest that muscarinic-stimulated inositol phosphate releasi: occurs at the level of the outer hair cell and thus may have an important modulatory role in auditory transduction.
\end{abstract}

Cochlea; Efferents; Inositol; Muscarinic receptor; Outer hair cell; Second messengers

\section{Introduction}

Outer hair cells of the mammalian inner ear receive the majority of the cholinergic efferent innervation of the organ of Corti (Spoendlin, 1985). It is uncertain, however, whether the putative cholinergic receptor of the outer hair cell is nicotinic or muscarinic. Both nicotinic and muscarinic antagonists block efferent effects in the cochlea (Bobbin and Konishi, 1974). Binding of $\alpha$-bungarotoxin, indicative of nicotinic receptors, has been demonstrated on isolated outer hair cells (Canlon et al., 1989). Conversely, quinuclidinylbenzilate binding has been found in the rat cochlea, suggesting the presence of muscarinic receptors at the efferent synapse (Megen et al., 1988).

Acetylcholine is known to stimulate the hydrolysis of phosphatidylinositol 4,5-bisphosphate $\left(\mathrm{PtdIns}_{2}\right)$ via muscarinic receptors as the initial event in a transmembrane signalling system in a variety of cells (Fisher et al., 1983). There is increasing evidence that this phosphoinositide-based second messenger cascade is also

\footnotetext{
Correspondence to: Jochen Schacht, Kresge Hearing Research Institute, University of Michigan, $12 n, \ldots$ nn Street, Ann Arbor, MI 48109-0506, USA. Fax: (313) ,

1 Parts of this study were presented at two meetings (Ono and Schacht, 1987; Niedzielski and Schacht, 1991a).
}

associated with efferent mechanisms in the cochlea. ${ }^{32} \mathrm{P}$-labeling of phosphoinositides has been observed qualitatively in isolated outer hair cells (Williams et al., 1987); acoustic stimulation increased phosphoinositide hydrolysis in the organ of Corti (Ono and Schacht, 1989); and inositol trisphosphate elicited contractions in permeabilized outer hair cells (Schacht and Zenner, 1987).

We have previously demonstrated a cholinergic activation of phosphoinositide hydrolysis in the organ of Corti in vivo (Ono and Schacht, 1987). Cholinergic control of phosphoinositide hydrolysis in the inner ear was subsequently confirmed and characterized as muscarinic in the developing rat cochlea in vitro (Guiramand et al., 1990). In contrast to the developing rat, carbachol-induced inositol phosphate (IP) release was significantly lower in adult animals (Bartolami et al., 1990). The preparation utilized in the latter studies contained both organ of Corti and modiolar tissue. Since it has been suggested that $90 \%$ of the muscarinic receptors in the cochlea are present in the modiolus (James et al., 1983) the location of the inositol effect remained uncertain. In order to exclude the effects of modiolar muscarinic receptors, our present investigation examined stimulated phosphoinositide hydrolysis in the isolated organ of Corti of the mature guinea pig in vitro. Mature animals were selected to assure that any observed effects reflected normal auditory process- 
ing rather than developmental phenomena. In addition, we investigated the longitudinal distribution of carbachol-stimulated IP release because of our recent findings of base-to-apex differences in phosphoinositide metabolism and protein phosphorylation (Niedzielski and Schacht, 1991a, 1991b; Coling and Schacht, 1991). Information on the longitudinal distribution of cochlear phosphoinositide hydrolysis is important in order to extend the anatomical evidence of a gradient in efferent cholinergic innervation to a functional difference between the base and the apex of the organ of Corti.

\section{Methods}

\section{Phospholipid hydrolysis in tivo}

To label phospholipids in vivo, [ $\left.{ }^{32} \mathrm{P}\right]$-orthophosphate ( $\left.{ }^{32} \mathrm{Pi}\right)$ was introduced into the inner ear of adult pigmented guinea pigs (300-400 g) via perilymphatic perfusion as described previously (Nuttall et al., 1977; Takada and Schacht, 1982). The cechlea was perfused for a $15 \mathrm{~min}$ stabilization period prior to the introduction of artificial perilymph containing $100 \mu \mathrm{Ci}^{32} \mathrm{P}_{\mathrm{i}} / \mathrm{ml}$ (ICN Radiochemicals, Irvine, CA). After $30 \mathrm{~min}$, the perfusion with ${ }^{32} \mathrm{Pi}$ was stopped and the perfusate remained in the cochlea for an additional $60 \mathrm{~min}$. Thereafter, a 60 min 'chase' was performed with artificial perilymph containing ! $\mathrm{mM} \mathrm{NaH} \mathrm{PO}_{4}$ and $1 \mathrm{mM}$ carbachol chloride. At the end of the experiment, the perilymphatic space was perfused with $10 \%$ neutralized formaldehyde and the temporal bone was fixed in the same solution (Orsulakova et al., 1976). The organ of Corti (hair cells, supporting cells, nerve fibers) was dissected from all turns. Lipids were extracted, separated by thin-layer chromatography, and identified as described (Orsulakova et al., 1976; Schacht, 1981). Individual ${ }^{32} \mathrm{P}$-containing lipids were scraped off the plates and quantified by liquid scintillation counting.

\section{In-litro tissue preparation}

Organ of Corti tissue was isolated from the cochleae of adult pigmented guinea pigs by microdissection. The viability of this preparation during in-vitro incubations was assayed by a double-staining procedure with propidium iodide and the carboxyfluorescein probe BCECF-AM (Molecular Probes, Eugene, OR) essentially as used previously for isolated outer hair cells (Dulon et al., 1989). Organ of Corti was incubated for $30 \mathrm{~min}$ at $37^{\circ} \mathrm{C}$ followed by an additional $60 \mathrm{~min}$ in the presence of $10 \mu \mathrm{M}$ BCECF-AM. The tissue was then transferred to $50 \mathrm{ml}$ of HBSS on a microscope slide and $1 \mu \mathrm{M}$ propidium iodide (final concentration) was added. Fluorescence of the samples showed that both basal and apical tissue was stained green with BCECF; no red staining with propidium iodide was observed.
This indicated that cochlear tissue remained viable under these conditions.

\section{Inositol phosphate release in vitro}

The inositol lipid pool was prelabeled by incubating the isolated organ of Corti for $2 \mathrm{~h}$ at $37^{\circ} \mathrm{C}$ in $50 \mu \mathrm{l}$ of Hanks' balanced salt solution (HBSS, $\mathrm{pH}$ 7.4) enriched with $1 \mathrm{mM}$ cytidine and $20 \mu \mathrm{Ci} m y o-\left[2-{ }^{3} \mathrm{H}\right]$ inositol (Amersham, Arlington Heights, IL). After removing the $\left[{ }^{3} \mathrm{H}\right]$ inositol-medium and washing the tissue twice with $0.5 \mathrm{ml}$ HBSS, the incubation was continued for 10 min in $90 \mu \mathrm{l}$ of HBSS containing $10 \mathrm{mM} \mathrm{LiCl}$. At this time, cholinergic agonists or antagonists were added. Following an additional $30 \mathrm{~min}$ at $37^{\circ} \mathrm{C}$, the incubation was terminated with $300 \mu$ l chloroform/methanol $(1: 2$, by volume) and aqueous and chloroform phases were partitioned. Total IPs were separated from inositol on Dowex formate columns (Dean and Beaven, 1989). Radioactivity in the column fractions was determined by liquid scintillation counting.

\section{Results}

\section{Phospholipid hydrolysis in tivo}

The time course of phospholipid labeling in vivo has been established previously (Ono and Schacht, 1989). After $90 \mathrm{~min}$ of perfusion, PtdIns $\mathrm{P}_{2}$ was the most highly labe! d lipid in the organ of Corti. After the 60 min chase, the ${ }^{32} \mathrm{P}$-PtdInsP $\mathrm{P}_{2}$ constituted $31 \%$ of total labeled lipids in the organ of Corti. With $1 \mathrm{mM}$ carbachol present in the chase perfusion, the relative PtdInsP $P_{2}$ content was reduced from $31 \%$ to $21 \%$, indicating stimulated hydrolysis. The pharmacology of this effect was then studied in detail in vitro via the release of inositol phosphates IPs from phosphoinositides prelabeled with ${ }^{3} \mathrm{H}$-inositol.

\section{Inositol phosphate release in vitro}

The in-vitro experiments essentially used the preparation of the organ of Corti in which we have previously characterized phospholipid metabolism in adult guinea pigs (Niedzielski and Schacht, 1991b). Organ of Corti from one cochlea (average protein content, 8.8 $\mu \mathrm{g})$ was required for each experimental condition. Normally, four cochleae, and thus four conditions, were employed in an experiment.

Carbachol $(1 \mathrm{mM})$ caused an approximately 2-fold increase of IP release (Table I). This was similar to the effects of $1 \mathrm{mM}$ muscarine, which stimulated IP release 1.6-fold. In contrast, dimethylphenylpiperazinium (DMPP), a nicotinic agonist, did not increase IP levels significantly over controls. Such rates of stimulation are comparable to those determined in other tissues. For example, $1 \mathrm{mM}$ carbachol elicited a 2-fold (Gonzales and Crews, 1984) or an 8-fold increase in 
TABLE I

EFFECT OF CHOLINERGIC AGONISTS ON THE RELEASE OF INOSITOL PHOSPHATES IN THE ORGAN OF CORTI

\begin{tabular}{ll}
\hline Condition & Inositol phosphate released \\
\hline & $\mathrm{dpm}^{3} \mathrm{H}-\mathrm{IPs} / \mu \mathrm{g}$ protein \\
control & $373 \pm 83$ \\
carbachol $(1 \mathrm{mM})$ & $643 \pm 87 *$ \\
muscarine $(1 \mathrm{mM})$ & $599 \pm 61^{*}$ \\
DMPP $(30 \mu \mathrm{M})$ & $365 \pm 92$ \\
\hline
\end{tabular}

Isolated organ of Corti was incubated with agonist for $30 \mathrm{~min}$ in the presence of $10 \mathrm{mM} \mathrm{LiCl}$ according to 'Methods'; Values are means \pm S.D. $(N=4) .{ }^{*}$ significant difference from control $(P<0.05$; paired $t$-test).

TABLE II

EFFECT OF MUSCARINIC ANTAGONISTS ON STIMULATED INOSITOL PHOSPHATE RELEASE

\begin{tabular}{ll}
\hline Condition & Inositol phosphate released \\
\hline & $\mathrm{dpm}{ }^{3} \mathrm{H}-\mathrm{IPs} / \mu$ g protein \\
control & $426 \pm 46$ \\
carbachol $(1 \mathrm{mM})$ & $916 \pm 165 *$ \\
carbacho $(1 \mathrm{mM})$ and & \\
$\quad$ atropine $(1 \mu \mathrm{M})$ & $496 \pm 70$ \\
atropine $(1 \mu \mathrm{M})$ & $438 \pm 55$
\end{tabular}

Experimental procedures are similar to those described in Table $\mathrm{I}$. Values are means \pm S.D. $(N=4)$. ${ }^{*}$ significant difference from control, $P<0.01$.

TABLE III

EFFECT OF ANTAGONISTS ON STIMULATED INOSITOL PHOSPHATE RELEASE

\begin{tabular}{ll}
\hline Condition & Inositol phosphate released \\
\hline $\begin{array}{l}\text { control } \\
\text { carbachol }(1 \mathrm{mM})\end{array}$ & $305 \pm 23$ \\
$\begin{array}{l}\text { carbachol }(1 \mathrm{mM}) \text { and } \\
\quad \text { mecamylamine }(1 \mu \mathrm{M})\end{array}$ & $575 \pm 119 *$ \\
$\begin{array}{l}\text { carbachol }(1 \mathrm{mM}) \text { and } \\
\text { strychnine }(1 \mu \mathrm{M})\end{array}$ & $559 \pm 104 *$ \\
\hline
\end{tabular}

Experimental procedures are similar to those described in Table $\mathbf{I}$. Values are means \pm S.D. $(N=4)$. * significant difference from control $(P<0.01 ;$ paired $t$-test $) ; * *$ significant difference from control $(P<0.05$; paired $t$-test).

\section{TABLE IV}

APEX TO BASE DIFFERENCES IN STIMULATED INOSITOL PHOSPHATE RELEASE

\begin{tabular}{llrl}
\hline Tissue & \multicolumn{3}{l}{ Inositol phosphate released } \\
\hline & \multicolumn{2}{l}{ Control } & Carbachol \\
& dpm ${ }^{3} \mathrm{H}-\mathrm{IPs} / \mu \mathrm{g}$ protein & $\%$ stimulation \\
\cline { 2 - 3 } apical tissue & $483 \pm 57$ & $874 \pm 226$ & $180 \pm 30$ \\
basal tissue & $324 \pm 91$ & $1079 \pm 526$ & $330 \pm 100 *$ \\
\hline
\end{tabular}

Experimental procedures are similar to those described in Table I. Carbachol concentration was $10 \mathrm{mM}$. Values are means \pm S.D. $(N=$ 5). ${ }^{*}$ significant difference from apical tissue $(P=0.04$; paired $t$-test $)$.
IPs (Godfrey et al., 1990) in rat brain slices stimulated for $30 \mathrm{~min}$.

The succeeding set of experiments further characterized the pharmacology of the cholinergic response. There was little variability in unstimulated IP release between experiments (compare Tables I-III) and the effect of carbachol was also consistent. The stimulated release was suppressed to near control levels by $1 \mathrm{mM}$ atropine, a muscarinic receptor antagonist (Table II). Atropine had no effect on unstimulated accumulation of IPs. Neither $1 \mu \mathrm{M}$ mecamylamine, a nicotinic antagonist, nor strychnine, a known blocker of cochlear efferent nerve stimulation (Desmedt and Monaco, 1961), suppressed carbachol-mediated IP release in the organ of Corti (Table III).

A final series of experiments examined the base/apex distribution of this stimulated turnover (Table IV). Ten mM carbachol was utilized to ensure saturation of the muscarinic receptors. In the basal portion of the organ of Corti, stimulated IP levels were 3.3-fold higher than controls. In contrast, stimulation in the apex was only 1.8-fold (significant difference, $P<0.04$, by paired $t$-test). Atropine $(10 \mu \mathrm{M})$ was equally effective in blocking carbachol-stimulated IP release in both base and apex (data not shown).

\section{Discussion}

In the organ of Corti, the phosphoinositide second messenger system is under muscarinic cholinergic control and probably associated with efferent action on outer hair cells. Evidence comes from both in-vivo and in-vitro studies of PtdIns $\mathbf{P}_{2}$ hydrolysis and IP release, two complementary measures of the activity of the phosphoinositide second messenger system. Carbachol and muscarine stimulated and the muscarinic antagonist atropine blocked phosphoinositide metabolism, while the nicotinic agonists and antagonists had no effect. This pharmacological evidence for muscarinic receptor-mediated phosphoinositide hydrolysis in the organ of Corti of the mature guinea pig complements the results of Guiramand et al. (1990), who determined that a $M_{3}$ muscarinic receptor activates the phosphoinositide cascade in the inner ear of the developing rat.

These results do not rule out the existence of nicotinic receptors in the cochlea, and in fact there is considerable evidence that such receptors are also present. This includes anatomical studies on bungarotoxin (Canlon et al., 1989) and antibody binding (Plinkert et al., 1990), and physiological studies on the effects of nicotinic antagonists on cochlear potentials (Bobbin and Konishi, 1974; Fex and Adams, 1978). Although the presence of both muscarinic and nicotinic receptors is likely, it is clear from the present experiments that only cochlear muscarinic receptors are coupled to 
phosphoinositides in the cochlea. This is consistent with the general pharmacolcgy of cholinergic activation of phosphoinositide hydrolysis.

There are two known targets for the cholinergic efferent innervation of the cochlea: the outer hair cells and the afferent dendrites at the level of the inner hair cells. These two types of innervation are inversely distributed along the cochlea. More efferents innervate outer hair cells in the basal cochlea while the axodendritic efferent innervation at the inner hair cells predominates in the apex (Spoendlin, 1985). The higher stimulation of IP release in the basal organ of Corti suggests a muscarinic receptor-coupled transduction system at the efferent synapse of the outer hair cell.

What is the role of muscarinic efferent transduction in cochlear physiology? A current model for the role of outer hair cells postulates that they provide a positive feedback mechanism in transduction (Neely and Kim, 1986) based on their motile response to electrical stimulation (Brownell et al., 1985). Qualities of this response such as threshold, time course, or magnitude will be influenced by the physical state of the cell, for example its turgor, and by the biochemical state of the subcellular components engaged in the response. We postulate that this homeostasis of outer hair cells is under the control of the muscarinic efferent system via the regulation of intracellular calcium levels.

In support of this model, elevation of intracellular calcium by ionophores induces changes in turgor and shape of isolated outer hair cells via calcium/ calmodulin-dependent mechanisms (Dulon et al., 1990). Consistent with such a mechanism is the presence of calcium/calmodulin-dependent protein kinases (Coling and Schacht, 1991) and contactile proteins in the organ of Corti. Actin (Flock et al., 1986; Slepecky, 1989) and spectrin (Holley and Ashmore, 1990; Ylikoski et al., 1990) have been localized to submembrane areas of outer hair cells. The cortical cytoskeleton in this region of the cell is organized into a helical apparatus (Holley and Ashmore 1988, 1990) which may be capable of altering tension or shape of the cell.

By their ability to elevate intracellular caicium levels, both voltage-gated calcium channels and the muscarinic efferent system are potential physiological regulators of outer hair cell homeostasis. Binding of acetylcholine to muscarinic receptors leads to the formation of diacylglycerol and inositol trisphosphate $\left(\mathrm{IP}_{\mathbf{3}}\right)$ as seen here. The latter, in turn, binds to intracellular receptors and releases calcium stores. Reports on outer hair cells in vitro do not agree whether acetylcholine can directly alter hair cell shape (Brownell et al., 1985; Slepecky et al., 1988; Bobbin et al., 1990). Furthermore, small acetylcholine-induced contractions in isolated outer hair cells were blocked by the nicotinic antagonist curare (Plinkert et al., 1990) suggesting a mediation of this motile response via ion channels.
Therefore, the muscarinic cholinergic system may affect outer hair cell motility by an indirect mechanism.

This could be accomplished by the actions of diacylglycerol and the $\mathbf{I P}_{3}$-sensitive calcium pool. $\mathbf{I P}_{3}$-dependent calcium and diacylglycerol could activate calmodulin-dependent kinases or the family of protein kinase C (Nishizuka, 1989) whose presence we have also confirmed for the organ of Corti (Coling and Schacht, 1991). In addition to the previously described changes in turgor, calcium levels and protein phosphorylation may modulate other processes of relatively long time courses (milliseconds and longer) including conductance states of ion channels, responsiveness of structural elements and synaptic events. Thus, in response to efferent transmitters or modulators (e.g. ATP; Niedzielski and Schacht, 1991c) the phosphoinositide second messenger system may modulate the characteristics of the voltage-driven outer hair cell motility.

\section{Acknowledgement}

This research was supported by NIH program project grant DC-00078 and training grant DC-00011.

\section{References}

Bartolami, S., Guiramand, J., Lenoir, M., Pujol, R. and Recasens, M. (1990) Carbachol-induced inositol phosphate formation during rat cochlea development. Hear. Res. 47, 229-234.

Bobbin, R.P., Fallon, M., Puel, J.-L., Bryant, G., Bledsoe, S.C., Zajic, G. and Schacht, J. (1990) Acetylcholine, carbachol, and GABA induce no detectable change in the length of isolated outer hair cells. Hear. Res. 47, 39-52.

Bobbin, R.P. and Konishi, T. (1974) Action of cholinergic and anticholinergic drugs at the crossed olivocochlear bundle hair cell junction. Acta Otolaryngol. 77, 56-65.

Brownell, W.E., Bader, C.R., Bertrand, D. and de Ribaupierre, Y. (1985) Evoked mechanical responses of isolated cochlear outer hair cells. Science 227, 194-196.

Canlon, B., Cartaud, J. and Changuex, J.P. (1989) Localization of $\alpha$-bungarotoxin binding sites on outer hair cells from the guineapig cochlea. Acta Physiol. Scand. 137, 549-550.

Coling, D.E. and Schacht, J. (1991) Protein phosphorylation in the Organ of Corti: Differential regulation by second messengers between base and apex. Hear. Res. 57, 113-120.

Dean, N.M. and Beaven, M.A. (1989) Methods for the analysis of inositol phosphates. Anal. Biochem. 183, 199-209.

Desmedt, J.E. and Monaco, P. (1961) Mode of action of the efferent olivocochlear bundie on the inner ear. Nature 193, 1263-1265.

Dulon, D., Zajic, G., Aran, J-M. and Schacht, J. (1989) Aminoglycoside antibiotics impair calcium-entry but not viability and motility of cochlear outer hair cells. J. Neurosci. Res. 24, 338-346.

Dulon, D., Zajic, G. and Schacht, J. (1990) Increasing intracellular free calcium induces circumferential contractions in isolated cochlear outer hair cells. J. Neurosci. 10, 1388-1397.

Fex, J. and Adams, J.C. (1978) a-Bungarotoxin blocks reversibly cholinergic inhibition in the cochlea. Brain Res. 159, 440-444. 
Fisher, S.K., Klinger, P.D. and Agranoff, B.W. (1983) Muscarinic agonist binding and phospholipid turnover in brain. J. Biol. Chem. 258, 7358-7363.

Flock, A., Flock, B., Ulfendahl, M. (1986) Mechanisms of movement in outer hair cells and a possible structural basis. Arch. Otorhinolaryngol. 243, 83-90.

Godfrey, P.P., Taghavi, Z., Parfrey, H. and Grahame-Smith, D.G. (1990) Differential effects of lithium on agonist-stimulated inositol polyphosphate formation in rat cerebral cortex slices: Selective actions on muscarinic cholinergic responses. Neurochem. Int. 17. 515-522.

Gonzales, R.A. and Crews, F.T. (1984) Characterization of the cholinergic stimulation of phusphoinositide hydrolysis in rat brain slices. J. Neurosci. 4, 3120-3127.

Guiramand, J., Mayat, E., Bartolami, S., Lenoir, M., Rumigny, J.-F., Pujol, R. and Recasens, M. (1990) $\mathrm{A} \mathrm{M}_{3}$ muscarinic receptor coupled to inositol phosphate formation in the rat cochlea? Biochem. Pharmacol. 39, 1913-1919.

Holley, M.C. and Ashmore, J.F. (1988) A cytoskeletal spring in cochlear outer hair cells. Nature 335, 635-637.

Holley, M.C. and Ashmore, J.F. (1990) Spectrin, actin and the structure of the cortical lattice in mammalian cochlear outer hair cells. J. Cell Sci. 96, 283-291.

James, W.M., Cheatham, M.A. and Klein. W.L. (1983) Muscarinic acetylcholine receptor binding in the guinea pig cochlea. Hear. Res. 9, 113-121.

Megen, Y.J.B. van, Klaassen, A.B.M., Rodrigues de Miranda, J.F. and Kuijpers, W. (1988) Cholinergic muscarinic receptors in rat cochlea. Brain Res. 474, 185-188.

Neely, S.T. and Kim, D.O. (1986) A model for active elements in cochlear biomechanics. J. Acoust. Soc. Am. 79:1472-1480.

Niedzielski, A. and Schacht, J. (1991a) Phosphoinositide metabolism in the cochlea: distribution of enzymes and carbachol-stimulated turnover. Abstr. Assoc. Res. Otolaryngol. 14, 135.

Niedzielski, A.S. and Schacht, J. (1991b) Phospholipid metabolism in the cochlea: Differences between base and apex. Hear. Res. 57 , 107-112.

Niedzielski, A. and Schacht, J. (1991c) P2 purinoceptors stimulate inositol phosphate release in the guinea pig organ of Corti. Soc. Neurosci. Abs. 17:1213.

Nishizuka $Y$. (1989) The family of protein kinase $\mathrm{C}$ for signal transduction. J. Am. Med. Assoc. 262, 1826-1833.
Nuttall, A.L., Marques, D.M. and Lawrence, M. (1977) Effects of perilymphatic perfusion with neomycin on the cochlear microphonic potential in the guinea pig. Acta Otolaryngol. 83, 393-400.

Ono, T. and Schacht, J. (1987) Effect of cholinergic agents on phospholipid metabolism in the guinea pig cochlea. Audiol. Japan 30:607-608.

Ono T. and Schacht J. (1989) Acoustic stimulation increases phosphoinositide breakdown in the guinea pig cochlea. Neurochem. Int. 14, 327-330.

Orsulakova A., Stockhorst E. and Schacht J. (1976) Effect of neomycin on phosphoinositide labeling and calcium binding in guinea pig inner ear tissues in vivo and in vitro. $J$. Neurochem. 26, 285-290.

Plinkert, P.K., Gitter, A.H., Zimmermann, U., Kirchner, T., Tzartos, S. and Zenner, H.P. (1990) Visualization and functional testing of acetylcholine receptor-like molecules in cochlear outer hair cells. Hear. Res. 44, 25-34.

Schacht J. (1981) Extraction and purification of polyphosphoinositides. In: S.P. Colowick and N.O. Kaplan (Eds.), Methods in Enzymology vol. 72D, Academic Press, New York, pp. 626-631.

Schacht, J. and Zenner H.-P. (1987) Evidence that phosphoinositides mediate motility in cochlear outer hair cells. Hear. Res. 31, $155-160$.

Slepecky, N., Ulfendahl, M. and Flock, A. (1988) Shortening and elongation of isolated outer hair cells in response to application of potassium gluconate, acetylcholine and cationized ferritin. Hear. Res. 34, 119-126.

Slepecky, N. (1989) Cytoplasmic actin and cochlear outer hair cell motility. Cell Tissue Res. 257, 69-75.

Spoendlin, H. (1985) Anatomy of cochlear innervation. Am. J. Otolaryngol. 6, 453-467.

Takada A. and Schacht J. (1982) Calcium antagonist and reversibility of gentamicin-induced loss of cochlear microphonics in the guinea pig. Hear. Res. 8, 179-186.

Williams, S.A., Zenner, H.-P. and Schacht, J. (1987) Three molecular steps of aminoglycoside ototoxicity demonstrated in outer hair cells. Hear. Res. 30, 11-18.

Ylikoski, J., Pirvola, U., Narvane, O. and Virtanen, 1. (1990) Nonerythroid spectrin (fodrin) is a prominent component of the cochlear hair cells. Hear. Res. 43, 199-204. 